\title{
Genetic Study on Aesthetic and Metaphysical Tension of Chinese Jade in a Dream of Red Mansions
}

\author{
Juan Wu \\ School of Foreign Language, Beijing Institute of Technology, China
}

Copyright $\mathrm{C} 2016$ by authors, all rights reserved. Authors agree that this article remains permanently open access under the terms of the Creative Commons Attribution License 4.0 International License

\begin{abstract}
This paper starts from the jade image in literary narratives, A Dream of Red Mansions to the genetic study on jade mythological concepts to illustrate the aesthetic and metaphysical tension of jade, to illustrate the particular characteristics of Chinese culture, to reveal the underlying mythological concepts that dominate the ritual behaviors and literary narratives, and highlight the prototype function of mythological concepts in the construction of the jade ideology and narratives. Once the prototype of jade myth is revealed, the evolvement track of its cultural narratives and the operative relations between coding and re-coding will be better understood. Besides, the scope and subject of jade study extends from literary narratives in written form to the pre-writing prehistoric jade articles for worshiping purposes.
\end{abstract}

Keywords Chinese Jade, Aesthetic, Metaphysical, A Dream of Red Mansions

\section{Introduction}

Magic treasures appear in almost all mythological narrations relating to the ancient heroes or kings. As the luster and colour of gold obsessed the Greek and Roman writers, jade is valued and worshiped continuously that Chinese civilization has for several-thousand-year experienced a "Jade Age" right from the beginning of its formation. Gold has had a history of around 3000 to 4000 years, while jade of around 7000 to 8000 years, twice that of gold. Though the economic value of some other natural resources, such as gold, silver, bronze and iron, are emphasized as well in these narratives, none of them could compete with jade in the way that it closely connected to the origin of Chinese civilization. In A Dream of Red Mansions (Honglou Meng also known as The Story of the Stone) [1], a novel by Cao Xueqin, the relationship between Jia Baoyu, the protagonist, and his mysterious Tongling Jade (The Precious Jade of Spiritual Percept). The precious jade of spiritual perception was far more than a piece of beautiful, refined and elegant jade, but a token of moral integrity, an identity of the rigid feudal hereditary, a holy connection with the heavenly will, a symbol of supreme sublimity and preciousness. Max Weber holds that, "The supreme gold of social sciences is not to pursue the construction of new ideas or new concepts, but to make efforts in understanding the cultural meaning of concrete historical links". [2: 60] To explore the source of jade worship, the literary narrative and mythological concepts shall be studied simultaneously. This paper hopes to explore jade on both the theoretic and practical level and make some contribution through integrating the profound heritage of Chinese culture.

\section{Quadruple Evidences of Chinese Mythology and Diachronic Decoding of Cultural Sign}

Chinese mythological mode of exploring civilization origins has its distinctive characteristics and unique approach. Although influenced deeply by the western mythology studies, the Chinese mythology school is deeply grounded in the native land and offers some novelties and nuances. The initial development can be traced back to the early 1980s, when a number of scholars, with Yuan Ke foremost among them, made the abundance of Chinese myths clear to mythologists and sinologists alike. In fact, as early as in 1933 Chinese scholars had started to question the validity of the prevalent view that myths in China are scarce, fragmentary and unsystematic and they rejected such a view as "a profound mistake" or "a false proposition" [3: xi] and argued instead that "despite their protean and contradictory forms, Chinese myths are more reliable documentary evidence of a primitive and archaic oral tradition in the world of myth." [3: xii]. For the new generation of Chinese scholars, the problem of myth is no longer why Chinese myths are so far and few in between, but how to recover lost myths and advance comparative mythology through up-to-date approaches.

In the 1980 s, a younger generation of scholars emerged, especially the new Chinese mythology school led by Xiao Bing and Ye Shuxian, who applied archetypal theories and 
cultural anthropology to the rediscovery and reconstruction of Chinese mythology. Supported by archaeological findings over the past few decades and mythological theories like those of Mircea Eliade and Roland Barthes, this school differs from earlier scholars such as Mao Dun and Yuan Ke who confined myths to the realm of literature. Instead, it propagates literary anthropology and advocates a paradigm shift in Chinese mythology, to treat myth as the cultural gene, social code and psychological source from which literature, art, philosophy, religion, politics, education, law, etc. all sprang. The "literature" and "philosophy" in myths is associated by mythological images, while the reproduction of the authentic history in myths relies on the concept of "mythistory" which is brought up by Ye. Though it has its theoretical support in western mythological research, it is still closely rooted in Chinese native materials. Given mythology is multi-faceted and also the "prototype" that constructs Chinese civilization, Ye even uses the concept "Mythological China" to generalize the self-expression of Chinese civilization. Owing to the activation of myths' multi-interpretation capacity and the penetrating understanding of the relations between mythology and history, "Myth history" offers methodological support for Ye's deep exploration of the origins of Chinese civilization.

Besides, this school follows the Levi Straussian logic of mythical thought and contends that myths "derive their meaning as part of a system" and "their structural relationship can, to a certain extent be decoded" [4: 125]. Based on Wang Guowei's "Dual Evidences" (canonical texts and excavated documents) and Rao Zongyi's "Triple Evidences" (canonical texts, excavated documents and material objects) for textual criticism, this school proposes and advocates "Quadruple Evidences"---the literary textual evidence, the material evidence, the unearthed archeological evidence, and the anthropological evidence---seeking evidence from not only canonical texts and excavated documents but material culture, a narrative of objects and intangible heritage, which was usually studied by folklorists and ethnologists. [5: 1-8]. Such methodology of quadruple evidences attestation, however ambitious, theoretically surpasses previous scholars' practices, whose versatile expertise was primarily based on early Chinese philosophy and history, etymology and archaeology (e.g. ritual bronzes oracle bones, bamboo slips).

To address the logic sequence of "Quadruple Evidences", Chinese mythologists further borrowed and adopted a pair of western anthropological terms, the "Little Tradition" (the folk/unlettered) and the "Great Tradition" (the elites/literate), which were coined by Milton Singer and Robert Redifield when they studied the orthogenesis of Indian Civilization in Madras city. Great tradition is associated with the elites, literate and reflective few who are capable of analyzing, interpreting and reflecting cultural knowledge. Great tradition is a body of knowledge which functions as the beacon light of knowledge. In contradiction to this little tradition comprises the belief pattern, the institutions, the knowledge including proverbs, riddles, anecdotes, folk tales, legends, myths and the unlettered peasants who imbibe cultural knowledge from the great tradition. Chinese mythologists redefined the "Little Tradition" as the cultural tradition marked by metal and language characters and the "Great Tradition" as the cultural tradition before the appearance of characters, metals and nations [5: 8]. On the basis of redefinition of tradition, the Chinese mythology school proposes an effective diachronic coding theory of cultural sign. According to the chronological sequence, the multiple evidences were arranged as following: The 1st level (material): the material evidence, including the unearthed archeological and the anthropological evidences of objects and painting before the appearance of word, which functions as the archetypal coding and dominated by the mythical mode of thought. The 2nd level (word): the ancient word and the message implied, in the context of Chinese culture, that is the Chinese character and calligraphy. The 3rd level (text): the literary textual evidence, such as the Chinese classics of the early periods, and Homer of the Greece. The multi-level (multi-texts): the manifold recreation and evolution of the ancient cultural coding, until the contemporary to current modern era.

Based on the integrated methodology of "Quadruple Evidences" and the diachronic coding theory of cultural sign into Chinese literary studies, Ye Shuxian applies them to the re-interpretation of Chinese jade cultural heritage. Ye uses the early antique jades as a kind of "Object Narrative" to explore the literature and culture, which is the natural extension of his "Quadruple Evidences"; as his research on the literary anthropology has developed from the literature texts to the culture texts, the early jades also transferred from the "material evidence" of the multiple evidences of the literary anthropology to the material symbol of civilization origins, which makes "jade" an new alternative to bronze and deeply connected the logic progression of literary anthropology and the civilization exploration. Ye confirms the "Great Tradition" corresponded by jade as the source of the "Little Tradition" corresponded by bronze, which first identifies the relative pre-existence of jade in time. Ye explicitly places early jades in the context of Chinese civilization exploration in papers including My Stones[J] (Ethnic Arts Quarterly, 2012(3)), Mythological Analysis of the Origins of Chinese Jades - Taking Jades of Xinglongwa Culture as an Example [J], (Ethnic Arts Quarterly, 2012(3)), Shun Issued Jades to Tribe Leaders after the Abdication from Yao: the Myth History of the Two Legendary Rulers[J], (Ethnic Arts Quarterly, 2012(3)), Mythological Analysis of Chinese Civilization Exploration- Interviews with Ye Shuxian [J], (by Liao Mingjun, Ethnic Arts Quarterly, 2012(3)).In May, 2013, on the international symposium on literary anthropology held at the Shaanxi Normal University, Ye Shuxian, the leading scholar of Chinese literary anthropology, proposed a jade-oriented theory that Chinese jade function not only as a material symbol of civilizational origin, but also as a centripetal force that promote the development of prehistoric multi-cultures toward the integrated civilization of Central Plains. In the light of the 
theory, the theoretical innovation and the inner logics of the jade mythology should be exam to decode the origins and characteristics of Chinese civilization.

\section{Aesthetic and Moral Tension of Jade in $A$ Dream of Red Mansions}

In A Dream of Red Mansions(Honglou Meng also known as The Story of the Stone) [1], a novel by Cao Xueqin, the correspondence between the imperial seal and the supreme ruler was replaced by the relationship between Jia Baoyu, the hero, and his Tongling Jade (jade of beauty, spirit, precocity and virtue). A Dream of the Red Chamber is highly honoured as an inexhaustible novel, which plays an unprecedented significance in the Chinese literature and give rise to large quantity of criticism entitled "Red-ology". In the novel, one of the reason why the characters with "yu" (jade) in their name are distinguished by their obsessive pursuit of purity and innocence (i.e., Bao-yu, Dai-yu, and the nun Miao-yu) enjoy more of the narrator's sympathy than other characters, such as the sophisticated and well-mannered Xue Baochai could be deduced to the aesthetical and metaphysical connotation and of jade. The aesthetic truth provided by the novel could be accessible to the connotative, poetic diction, and is immune to the denotative, name-fact words. Jade, as a natural mineral, enjoy certain characteristics that are superior to other minerals. Firstly, it's formed in extremely harsh conditions, which makes it rare and special. Secondly, it has special physical properties, such as, the hardness, color and luster, and the touch. Numerous phrases and idioms in Shijing (Book of Odes), including "a gentleman is as gentle as jade", "a gentleman always wear jade", a gentleman shall cultivate his morals the way jade is sculpted - by "cutting, polishing, carving and rubbing", and the concept of "jade virtues": all these are related to jade's physical properties.

It is worthy to notice that the word of "jade" is associated with purity, innocence, sublimity, ideal virtues of the Confucian gentleman, yet the words of the "jade" and "desire" are homophones in Chinese. Thus, the reader is struck by the "contradiction between the anti-Confucian worldview constructed by Bao-yu, and his identification with a symbol that contains within itself an ideological discourse that is predominantly Confucian" [1: 121]. In the novel, the passion for purity, implied by the names of the novel's "jade"-characters, can only result in either a life of desire (e.g., the final fate of Miao-yu) or in tragic death (as in the case of Dai-yu), unless one leaves the world of desire altogether (as Bao-yu will do). Jade, together with other signs, such as the family name of "Zhen" (true, real, genuine, natural) and "Jia" (false, hypocritical) operate both on the metaphysical and the moral level.

At first we believe the narrator's sympathy tilts towards Lin Dai-yu, but later we learn that Baochai is perceived as a moral being far inferior to Dai-yu, and that "the value of a human being, for the narrator of the Dream, lies unambiguously in individuality" [1:136]. And when Xue Baochai, "a mere public self" [1:135], tries to comfort her aunt, who is distraught over the suicide of a female servant, she is accused of "Machiavellian exploitation" [1: 150]. The contradictory character of Bao-yu, as symbolized by the notions of the "wan-shi" (naughty /stubben stone), on the one hand, and the "ling-shi" (intelligent/spirit stone), on the other. The tension between the narrative logic and the mythological logic of jade going through the very beginning and the outcome. "In terms of both narrative logic and cultural unconscious, Dream reveals itself as a tale about the fatal attractions of constraints and a tragedy about an aborted ideological revolution" [1: 205]. Accordingly, the novel is taken as "a narrative that eventually comes to terms with what it problematizes" [1:205].

It is widely accepted that text is not a self-contained universe and that each text is written-and understood-on the basis of pre-existing knowledge that is developed and transformed in the act of writing or reading. Knowledge of prior text is an indispensable precondition for the understanding or interpretation. The Chinese sinology has a distinct characteristic, that any interpretation of the text should be sordidly based upon the Chinese classics and in the context of Chinese culture, as well as extra-textual, social and cultural contexts. This traditional cross reference is analogy to that intertextuality, "an ideological instrument to attack the concept of the founding subject as the originating source of fixed meaning in the text" [1:7]. A book on the lore of jade provides us with a fine example to ascertain the connotation of stone and jade, in which the author not only refer to the received edition of the novel but also consults earlier manuscript versions-a procedure that makes sense only if a pre-existing, unifying, authorial intention is assumed. The construction of a prior text against which to interpret the text of one's choice is in principle an infinite task and so, in practice, cannot escape a certain degree of arbitrariness. As the intimacy between stone and jade, the author treats them as contradictory, fixed essences. This predilection for fixed essences is coupled with a blatantly dualistic world-view: "The tragic dimension of the Dream achieves its depth and magnitude because of the structural tension that exists between stone and jade, between the divine and the secular, between the myth of the stone and the drama of the individual" [1:277]. The dualistic world-view is expressed by western terms, such as heaven, the fall, self-crucifixion, or "soaring spirits" who "aspire to tear themselves from the confines of their fragile and mortal flesh in an everlasting struggle" [1:268]. She concludes that "in such an epistemological vision the original is the eternal and the essential, and that which comes after it is its surrogate, already a subordinate, both transient and accidental in nature" [1:213].

The author Cao Xueqing, who is deemed as a "writer of high literary calibre" [1: 151], secures his position in the Chinese literary history, somewhat is analogy to the great 
dominance of William Shakespeare in the English Literature. Cao Xueqing is fully aware of the intertextual nature of his own work and Chinese jade culture very well, it would have been worthwhile to make a distinction between those texts that he consciously reworked in his own composition and those that, whether he knew them or not, rather functioned as constituents of the pervasive, social knowledge of his time. In A Dream of Red Mansions, description of the Jade's functions was more clear than in the Qin and Han dynasties, i.e. three mysterious functions were inscribed on the back of Tongling Jade: "first, drive away the evil spirits; second, heal chronic diseases,; third, know the weal and woe." [1: 154].

Cao Xueqing was truly the inheritor of the essence of Chinese jade culture. In the "third, know the weal and woe", i.e. the religious function of foreseeing the future, Jia Baoyu's Tongling Jade had surpassed the Emperor of Qin's imperial jade seal, which fully showed the continuity of jade religion's mythological beliefs from the Neolithic Age to the last dynasty of the feudal society. People in the age of the Emperor of Qin firmly believed that the jade seal can adequately represent the heaven's will to justify the emperor's ruling, which was the national belief, so the nation's highest orders should be issued and published in the particular way of "Xi Shu" (documents sealed by imperial jade )"; people in the age of Cao Xueqin still believed that jade articles can "tong ling" (meaning: psychic), i.e. relate to gods, which was a typical mythological function, while it was folk belief that Tongling Jade can protect its wearer's safety. Both the national belief represented by the king and the folk belief represented by the common people are the heritage of the profound tradition of jade beliefs' culture embodied in the Chinese characters. The historical records and the literary works of Chinese civilization, from different perspectives, reflected the same potential dominance of pre-state pre-historical jade beliefs in the coding and decoding of cultural texts' construction. [7]

\section{Literary Intertextuality and Geographical Philosophy of Jade Narratives}

The moral and metaphysical tension of jade in the $A$ Dream of Red Mansions should be traced back to the initial beliefs of Chinese cultures and civilizations in the prehistoric age, as Karl, a contemporary English historical theorist, holds that, "It is a faith, believing that every single incident results from one or several reason and it won't happen in a different way unless the reason or something of the reason changes" [8: 100], the initial beliefs of man should be traced back to all cultures and civilizations in the prehistoric age. The mythological concepts might become the common and effective research approach to identify the core concepts of a culture come into being from the perspective of the pre-historical tradition. Thus on the one hand, we should keep alert for the authoritative narration in history records, on the other hand, we should realize the dialectical tension between the truth and the fake within myths, the myths' possibility and capability of narrating history. Myth is absolutely not the exactly account of authentic history, but it takes efforts to penetrate through the fantastic mythical narration to perceive the authentic history or grasp the leading threats to authentic history. By elucidating the connection between mythical concepts narration and historical narration, mythology successfully gets rid of the narrow discipline limitation and is regarded as the common source and the integrated origin of the modern principles, like literature, history and philosophy. The historical and rational elements in myths, which shed light on the dialectics of mythical narratives. The discovering of underlying relation between mythology and history, the revealing of the dialectics within mythical narration offers methodological support for the deep exploration of the origins of Chinese civilization.

In the fourth chapter of $A$ Dream of Red Mansions, a sentence is used to describe the prosperity of Wang Xifeng's family is: "the East Sea lacks a white jade bed, so the Dragon King came to ask Duke of Jinling's help." The reason why the East Sea lacks white jade bed is that the white jades used to make the bed comes from the remote west regions, which is extremely far away from the East Sea. Only the richest families, like the rulers or kinsmen of the emperor or empress, have the power and privilege in transporting and possessing such rare resources in the large territory. So, even the Dragon King of the East Sea, a deity, also need to ask the help of the King of Jinling, an immortal, who has a rich stock of white jades, to realize the luxurious dream of owning a white jade bed. Since ancient times, the white jade has not only been high officials or royals' luxury to show off, but also a token of one's social status. Take the belt hook made of white jades as an example. In Story of the Embroidered Jacket: the Jacket to Protect Her Beloved from the Coldness written by Xu Lin of the Ming Dynasty, the hero said: "once, I also wore hat of horse hair, belt hook of white jade, balls of ambers, coat of ramie silk and leather boots." From this, we could see that the jade belt hood is a luxury unique to Chinese civilization, and that horn ornaments of white jade is especially precious and valuable. Cao Yan, the father of Cao Xueqin, once wrote a poem name as See the Moon at the Yellow River and Show It to Ziyou (Cao Yan's brother) when he was appreciating the moon at the bank of the Yellow River. In the poem, he said "only this white jade belt hook can stretch forward to the source of Kunlun", which can be interpreted as a pun. Why such a white jade belt hook "can stretch forward to the source of Kunlun"?

Firstly, Cao Yan thought of the white jade belt hook he was looking upwardly at the moon in the sky. Such association is not his personal imagination or creation, but a common practice of metaphor expression in the literary history - the shining moon in the sky looks like the white jade vessel in secular world that reflects white light. For 
example, in the poem Walking Under the Moon in Gulang, Li Bai said: "when I was young, I didn't know name of the moon, so I called it as a white jade plate." In his poem Feelings of Looking at the Moon in the Mid-Autumn Day, $\mathrm{Wu}$ Weiye of the Qing Dynasty said: "Until realizing the wisdom of waxing and waning in my late years, I start to worry about the future of the white jade plate." Now that the full moon shining white light makes people think of white jade plate, the slim crescent naturally makes people think of the white jade belt hook. Both the origin place of white jade and the source of the Yellow River are thought to be a large mountain in the western border of Chinese states - the Kunlun Mountain, thus Cao Yan connected two irrelevant natural objects - the moon and the Yellow River. He thought the moon as white jade, which also originates from Kunlun Mountain. He also imagined the Yellow River which flew to the east also originates there. The imagination about the Yellow River is thought to be something of "mythological geography", which is typical Chinese ancient geographical philosophy, i.e. mythological imaginations guide the real geographical thinking and the real geographical being is dominated and transformed by the imagined mythological concepts. The result is, the source of the Yellow River, which is in Qinghai province, is imagined to be in the far western mountain, i.e. the Kunlun Mountain south to the Tarim Basin in Xinjiang Province. In The Waters of Lop Nor: Part One, Volume One of Records of Waters in the Western Regions, Xu Song, the historian of the Qing Dynasty who specialized in the Western Regions, said: "Lop Nor is where the original source of the Yellow River stagnates and accumulates".

Here, Xu Song talked about the original source of the Yellow River, which was derived from the idea of "Yellow River's Double Sources", i.e. the Kunlun Mountain at Yutian, Xinjiang Province is the original source, which flew underneath from Kunlun to Lop Nor, and then comes out of the earth again when it arrived at Jishi Mountain (the second source) which was located at the border of Qinghai Province and Gansu Province. This theory solved the contradiction between "dredge the Yellow River at Jishi" in Shang Shu: Tribute of $\mathrm{Yu}$ and "the Yellow River originates from Kunlun" in Classic of Mountains and Seas, Records of the Grand Historian, Erya, etc. This theory solved the contradiction between "dredge the Yellow River at Jishi" in Shang Shu: Tribute of $Y u$ and "the Yellow River originates from Kunlun" in Classic of Mountains and Seas, Records of the Grand Historian, Erya, etc." [9: 47]

$\mathrm{Gu} \mathrm{Pu}$ of the Jin Dynasty, who annotated Classic of Mountains and Seas, was unable to clarify which place "Wu Da" referred to, so he had to say that it was name of a mountain. This caused trouble for locating where the Kunlun Mountain is. Viewed from the textual context of Classic of the Mountains: West, the Kunlun Mountain is about 1,300 Lis away from the famous mountain which produces the most beautiful jades in the world, and about 800 Lis away from the Zhongshan Mountain. All these mountains are part of the generalized Kunlun Mountains, which, the same as
Mount Tianshan and Qilian Mountain, are characterized with being high and steep, and covered with white snow. In the western cultural, the national psychology of worshiping the white color is to some degree connected to such natural geographical environment and conditions. Chinese usually compare the high peaks which are covered with snow all year long as the jade imperial peak, because the white snow and the white jade have similar colors.

In Xunzi: Dalue, Xunzi said: "Hire a person with Gui (an elongated pointed tablet of jade held in the hands by ancient rulers on ceremonial occasions), ask a scholar's help with $\mathrm{Bi}$, send for a person with Yuan (a jade ring with a big hole and small brim), break with a person with Jue (penannular jade ring), refuse to break with a person with Huan (a kind of jade ring)."Five jade sacrificial vessels have different meanings and functions. Among them, the fourth one (Jue) and the fifth one (Huan) are opposite and supplementary. In Guangyun, the authors said: "when an official is exiled to the frontier, if what he gets from the Emperor is Huan, it means that he can come back to the court; if what he gets is Jue, it means he won't be back any more." Na Zhiliang explained as: both jade Huan and jade Jue can be used as official tallies. Obviously, the exiled officials wanted very much the government's pardon, allowing them to go back home. Instead of any documents, either of two articles - Huan or Jue will be sent as an announcement by the government. Huan has the same pronunciation as another Huan (return), symbolizing the permit of returning home. Jue has the same pronunciation as another Jue (refuse, or reject), symbolizing that there is no pardon. [10: 178]. However, different from the general meaning of jade ring in Chinese culture, the white jade ring the Queen Mother of the West presented to the ruler of the Central Plains mainly conveyed the meaning of friendly communication.

As for the origin of Queen Mother of the West and the Kunlun myth, some modern scholars (represented by Sun Xuelin, Ding Shan, Du Erwei, Xue Gaoruan and Ling Chunsheng) influenced by foreign scholars like Hirth think that Xiwangmu is the goddess of the moon in the ancient civilization of the Tigris and Euphrates Valley in the Western Asia. When introduced to the Central Plains, it was translated into three Chinese characters, i.e. Xi (west) Wang (monarch) $\mathrm{Mu}$ (mother). People at that time were not clear about how Chinese jade culture passed on from the prehistoric period to the Shang and Zhou dynasties. Things are different now: numerous unearthed jade articles show us that, the jade rituals since Western Zhou Dynasty can't be without white jades and greenish white jades. But these jades are rare in the Central Plains, so the transportation of jades from the west to the east turned more and more fierce since the Xia, Shang and Zhou Dynasties, which supplied Hetian jades of Xinjiang (with white jade as the most precious) to the rulers of China. Based on this, we can see that the myth of Queen Mother of the West's presenting the white jade ting to the Emperor has its root in the reality, instead of being totally imaginative in cultures with no white jade worship. 


\section{Metaphysical Logic and Psychological Structure of Jade Narrative}

In order to grasp the core value of jade culture in $A$ Dream of Red Mansions, it's necessary to analyze the metaphysical logic and psychological structure of Jade mythology. Ye Shuxian, the leading scholar of Chinese mythology, explains the literary narratives of jade as the reflection of the great tradition of "jade-as-god". And the reason why jade is respected in the little tradition of Chinese civilization lies in the jade myths of 5000 years ago. "Jade myths" are particular to Chinese mythology, and the mythological mode of thoughts provides a multi-dimensional panoramic view of the origin of Chinese civilization. The psychoanalysis of jade is interpreted on the mystical witcheraft and magic in the comparative religious studies. Chinese jade, together with the western "hierophany" - gold and Lapis Lazuli, enjoys a holy and sublime status in the early civilization. The earliest "jade as god" appears in the great tradition of mythological world. Ye illustrates jade myths - Yellow Emperor plants jade, etc. - that starts from "the legendary Chinese ancestor Yellow Emperor and ends with the three wise rulers of Xia, Shang and Zhou dynasties." [11: 23] The analysis, stretching 2000 years, is the transition period from great tradition to little tradition. Ye "interpreted the little tradition of characters by the knowledge of great tradition" [11: 13], and verified the great tradition by the little tradition.

All of the six myths listed by Ye show jade's sanctity and function of connecting man and god. To be specific: Yellow Emperor's planting jade, recorded in The Classic of Mountains and Seas, shows that jade can increase the power of gods or ghosts and protect the gentlemen from the evil [11: 14]; the story that a jade article made Yu the Great the ruler of the country, as recorded in Shang Shu and Records of the Grand Historian, shows jade's sublime status in secular world [11: 16-17]; Qi of Xia going up to heaven with the ring of jade in his right hand and semi-circular jade wearing around his waist shows that semi-circular jades and jade wearing are all holy media that connect man and god [11: 19]; according to The Yizhoushu, Zhou, the last emperor of Shang dynasty, burned himself together with jade, which implies that jade can be smelted [11:20]; Jiang Ziya got semi-circular jade and the Duke of Zhou talked to the ancestors with jade sacrificial vessel, which shows that jade conveys mythical information [11: 21]; King Mu of Zhou visited the Yellow Emperor's Palace and got jade bough and jade leaf, which hints that the Yellow Emperor's Palace may be the palace where the worship of god with jades is performed [11:22].

The following jade myth is about Qi of Xia, who entered the heaven by gaining a semi-circular jade. As the son of $\mathrm{Yu}$ the Great, Qi was the creator of imperial family, i.e. the first who inherited the throne from his father. He also regarded the jade ware as the symbolism of supreme royalty. The difference was, the holy jade ware of $\mathrm{Yu}$ the Great is jade tablet, while that of Xia Qi was the semi-circular jade. The Classic of Mountains and Seas: Classic of Regions beyond the Seas said: "At Dale Ye, Xia Qi watched the musical dance Jiudai, and drove two dragons, flying beyond the clouds. In his right hand was a canopy, in his left hand a jade ring, and on his waist wore a semi-circular jade(according to Guo Pu's annotation: "a jade like half the sun"). Another saying goes that this happened to the north of the Dayun Mountain". [9: 209].

As the royal emperor, Qi of Xia was described as "in his left hand a jade ring, and on his waist wore a semi-circular jade". Seen from the great tradition of 8000-year-long jade culture, the appearance of jade tablet was much posterior to that of semi-circular jade. In other words, compared with the jade tablet of Yu the Great, Xia Qi's semi-circular jade bears more historical roots, whose cultural implication was also very rich. In 2007, the tomb No. 23(M23) discovered at Lingjia Tan, Hanshan County, Anhui Province, showed the splendid jade bearings of a tribal leader 5300 years ago: each of his hand wore 10 jade bracelets and on his body more than 300 jade articles, including a large number of semi-circular jades. This indicates that the description of Xia Qi in The Classic of Mountains and Seas is not purely imagined or created mythological literature at all. The custom of the ruler's wearing jades 4000 years ago resulted from the prehistoric tradition, that tribal rulers' wearing jades around 5000 to 6000 years ago. What require for further research are the mythological concepts behind the custom of wearing jades. Compared with the hundreds of jade articles discovered in the high-level tombs of Liangzhe Culture or Lingiia Tan Culture, Yu the Great and Qi of Xia only had one or two symbolical jade articles, as though representing the situation after the peak of jade culture or showing that jade culture tended to decline after the peak. The reason was that, with rise of state powers in the Central Plains, a new holy ironware (the bronze ware) appeared and gradually became popular. The great tradition of jade's domination transferred to the little tradition of co-existence of gold and jade.

The mythological concept behind the custom of rulers' wearing jades is mainly connected with the wizards' or priests' professional demand of access to the deities or heaven. In annotations to The Classic of Mountains and Seas, there are other versions about Xia Qi's entering the heaven by driving dragons. For example, Guo Pu explained: "according to Guizang: The Classic of Zhengmu, 'Qi of Xia rode the flying dragons to the heaven, which was auspicious'. Obviously, Qi was a deity too". Guo thought that Qi of Xia, who could go to heaven, enjoys privilege identity of becoming god. This was an interpretation of Xia Qi's entering heaven from the Taoist belief of West Jin dynasty. To the Qing dynasty, Hao Anxing cited another piece of information in his annotation: the 82nd volume of Imperial Readings of the Taiping Era cited Records of the Grand Historian that, "Qi of Xia once rode dragons to heaven. He asked Gao Yao to practice divination for him. Gao Yao said, 'it was auspicious to go there and 
communicate with the deities; and you will be the emperor ruling over the world"'.

The former three materials all talked about the special power of Xia Qi's riding dragons or entering the heaven by driving two dragons. The last material also told us about the purpose of going to the heaven, or communicating with the deities. Besides dragon driving, The Classic of Mountains and Seas also mentioned the jade articles: in his left hand a jade ring, and on his waist wore a semi-circular jade. The narration here had the meaning of origin: the source and holder of rites, music, songs and dances was Qi of Xia, the rider of two dragons. Since he could ride dragon, the text did not explain the reason why did he still held the jade ring in his hand and wore the semi-circular jade on his waist. Referring to another narration in The Classic of Mountains and Seas, we can know that jade ring and semi-circular jade functioned as the media between man and god: according to Classic of the Great Wilderness: West, "beyond the Southwest Sea, to the south of Chi River, and to the west of Drifting Sand, a man wore two green snake-sized jades and rode two dragons. The man was named Xia Qi. He three times visited the heaven, and went back down with Jiubian and Jiuge". [9: 414] The rites, music, songs and dances of the human world were thought to be brought down from the heaven by Xia Qi's three visits to the heaven. And the tool he used was still the dragons. When we put together the two mythological texts, we can summarize the basic formula of mythological concept of man-and-god combination which has to three interactive themes: the heaven visitor - riding dragons - wearing semi-circular jade (or holding jade ring)

In Painting Eulogies to The Classic of Mountains and Seas written by Guo Pu of Jin dynasty, these three themes were emphasized again: "What he drove was the flying dragons, and got the Jiudai dance. What he held was clouds. What he wore was jade. His imperial virtues were spread and his powers came from the celestial and covered all the nation." Why jade ware was combined with the theme of humans' communication with the deities or heaven? Bamboo Annals (Zhu Shu Ji Nian) also mentioned that, the special place where Qi of Xia holding rites was a dais decorated by jades: "in the winter of 841 BC, Emperor Qi ascended the throne...he feted the dunkes at Xuan Tai". Xuan Tian equals Zao Tai or Xuan Tai. Both Xuan and Zao refer to beautiful jades. So the emperor's power of access to the deities has something to do with his mysterious jade articles. In his Wen Xuan (Selections of Refined Literature), Wang Yuanchang said in Poem Preface to Qu River: "Qi of Xia rode the two dragons on the Xuan Tai (jade dais)." In his annotation to The Book of Changes, Li Shan said: "Qi of Xia once enjoyed music at the dyke of Jin River, and built Xuan Tai (jade dais) by the north side of the river". [12: 213]

Xuan Tai was a dais decorated by beautiful jades. As a dais name for Xia's emperor, Xuan Tai had more or less connection with the emperors after Xia and Shang dynasties. In his Chronicle of Emperors (Di Wang Shi Ji), Huangfu Mi wrote: "King Wu of Zhou ordered Duke Yuan to release the prisoned people and return the jades of Xuan Tai". In his Seven Orders, Zhang Xie of the Jin dynasty wrote that, "The rails were surrounded by clouds, with green walls and trees. There were eight guarded doors and Long Tai (Xuan Tai) was the ninth one". In later literatures, the dwellings of the deities were also called Xuan Tai. In the poem No. 10 of Guo Pu's Poetry about Immortals, he wrote: "Xuan Tai was the hat of Kunlun Mountain and wavered on the seaside of the West Sea". Kunlun, the production place of jade located in the west, was imagined as a mountain with a top like Xuan Tai. From these resources, we can see that, ancient people's memory of Xuan Tai didn't go beyond what was described in the age of Xia Qi. So, the same as the theme of dragon riding, the mysterious theme of jade dais, semi-circular jade, jade ring etc. carried some historical information which was prior to the Shang dynasty. In the interpretation of mythological stories, Ye Shuxian re-interpreted both the great and little tradition under the guide of the "jade-as-god" concept and presented the multi-dimensions of jade myths. The jade myths related to the kings of four dynasties -Xia, Shang, Zhou and Qin dynasties, covering a time span of more than 2000 years. From the analysis of them, we can see the continuation and evolution of jade's mythological concepts. Without understanding the conceptual tradition of jade myths, the later generations are subject to neglect the essential roles jades played in ancient historical narrations.

\section{Mythical Ideology and Mythological Concepts of Jade Narrative}

On the intimacy between mythology and politics and ideology, Schilbrack holds, "Mythological creation is no rare matter or mistake. It's nothing less than a way to make the political events easy to comprehend by way of ideological beliefs. After a long time, some narration seemed quite important for a social group; while, some others soon disappeared. But the creation and re-creation of mythological narrations is permanent in the political life." [13: 188]. In this statement, he stresses that mythological concepts plays a deterministic role and prototype function in the formation and evolution of ideology. Once the prototype of certain cultural community is revealed, the evolvement track of its historical cultural texts and the stable operative relations between coding and re-coding will emerge.

Without the mythological values of regarding gold as holy, the ancient Greek won't have the imaginative narration of gold age and gold apple. Similarly, without Chinese mythological values of worshiping jade as holy and immortal, Chinese won't have the mythological history of jade stories, including Bian He's presenting beautiful jade to the kings, Bi of $\mathrm{He}$ (Bi-a piece of jade with hole in center), and Wan $\mathrm{Bi}$ Gui Zhao (literal meaning-Bi came back to Zhao sound and safe, extended meaning-to return a thing intact to its owner), let alone First Emperor of Qin's imperial seal and Emperor Wu of Han's funeral rites of being buried with gold and jade 
clothes on. Thus our next task is to turn from the literary study of the mythology to the genetic or archaeological study on its mythological concepts, which is similar to the archaeology of knowledge proposed by Michel Foucault. Then, the scope and subject of mythology extends from ancient mythological narratives in written form to the pre-writing prehistoric jade articles for worshiping purposes. With an intention to figure out the underlying motives of human behaviors, the paper focuses on the deterministic role of mythological concepts in shaping the inward ideology and exterior behavior in the integrated view of ideological history and cultural history. Mythical narratives do not come out of vacuum and exist in an isolated realm. To figure out the operating mechanism of mythical narrative, it might be possible to reproduce the mental concepts dominating the sublime rulers.

Firstly, the competition for scarce resources at the birth of various civilizations. But the cause of competition is not the scarcity, but the underlying conceptual identical awareness, namely: both competing parties fight for the jades' infinite supernatural power, so the spiritual concepts disseminated together with the material competition. With the formation of jade's cross-cultural identity, the arduous pursuit for jade and the competition between tribes turned into the fight for social control and ideological power. Ye points out that: "the ideology molded by jade myths include the concepts of regarding jade as god, the symbol of celestial body and the symbol of eternal life, Shamanist rituals of worshiping god and ancestors with jade; folktales that respect and uphold jade; moral standards (virtues of jade) and teaching or learning patterns (cutting, polishing, scalping and rubbing) derived from jade; social practice of wearing jade (a gentleman must wear jade)"; linguistic customs formed from the supreme values of jade - names that contain jade (jade girl, Zhuanyu, Qiongyao, Tang Guizhang etc. ); numerous Chinese characters that is formed with jade as a component and various idioms and proverbs with the jade myths as the core information. The previous examples, through cultural transmission and interaction, constructed the state of royal powers in the Central Plain, and also the identity of many states and peoples beyond the Central Plain." [14: 29]

Viewing from the influences jade-as-god view has on the multi-aspects of Chinese society and life, the jade theory doesn't highlight the process of forming social entity through wars (which, of course existed), but the fusion of nation spirits on the basis of the widely acceptance of the jade-as-god concept. According to the jade theory, besides the physical unification of political community, namely, early state, the gradual formation of Chinese civilization also means the chelation of spiritual ideas, such as ideology. As a spiritual "chelate", jade-as-god view is more stable, which is embodied in both the heaven worshiping with jade in Shamanism and the gold medal inserted with jade in the 2008 Beijing Olympics. Ideology created by the jade-as-god view, surmounting the great and small tradition and integrating the spiritual and material, is the ultimate force that drives the formation of Chinese civilization. The road of jade provides a more dimensional view of the starting point of Chinese civilization.

Secondly, the competition among different regional cultures, both spiritual and material, is a comprehensive, whole-scale war during the forming of civilization, which is a force that leads to complexity. This force des not only initiate the bud of one single civilization, but the world-wide mutual initiation between various civilizations. Similarly, in one single civilization, with different groups sharing the same jade-as-god identity, they compete for jades and the jade-as-god view. The fight inside a society results in the formation of social strata and the supreme ruling class that monopolize the privilege of "worshiping god with jade". According to Discourses of Chu in the book Discourses of the States:

King Zhao of Chu asked Guan Shefu, "according to the Book of Zhou, Zhong and Li separated the heaven and the earth, why is that? If they didn't, can humans go up to the heaven?" Guan Shefu answered, "In Shao Hao's ruling, the Jiuli tribe didn't behave virtually. Man and god were mixed. Ceremonies were performed by ordinary people and Shamanism was done at home. There was no stress on god's holiness... when Zhuanyu took over the country, he ordered that Nan Zhengchong be in charge of the heaven and confer it to god and Huo Zhengli in charge of the earth and confer it to the man...which is the separating the man from the heaven." Zhuanyu's "separating the man from the heaven" is the process of limiting the power of man-and-god communication to the hand of the supreme rulers. Before this, "man and god were mixed" and "Shamanism was done at home" showed that, every human being can communicate with god, which is described on a broader scale of "Asian-American Shaman worship" by Kwang-chih Chang. Shaman is a representative of the winning class who has monopolized jade and the power to communicate with the heaven. This winning class, in that way of "the winner takes all", comprehensively monopolizes the resources and many other powers in the social entity. With "state" - this political entity - the supreme rulers take charge of the unpredictability of the power in "jade-as-god" view. Such mysteriousness of power is also reflected in the little tradition, such as the saying that "the holy jade of state can't be shown to ordinary men". In the ancient world, the mysterious power is the "charisma" in the sages, such as the Buddha, Mohammed, Confucius and Jesus; in modern world, the mysterious power is the "Mana" [11: 222] in native beliefs, which is defined by Max Weber as the charming personality "revealed" in those leaders. The social stratification and the consolidation of the supreme ruling class's status changed the body of society, from complex unity of multi powers to a relatively stable self-organized structure. After the consolidation of the social strata, there are a lot of internal stresses inside it, which has the potential of sudden outburst, like the infinite energy hidden inside the earth after its formation.

Thirdly, through the jade and ideology competition among different regional cultures, competition for the supernatural 
power is established among paralleled civilizations. Before the formation of the hierarchy political entity, i.e. state, the competition is among the different peoples in the same region and finally forms the ideological unity within which the peoples support and compete with each other. However, the competition among different cultures is the competition for the supernatural power. The transverse force that comes from the competition among different peoples in one same region is embodied, on one hand, in their fight for the supreme ruling power in the formation of states, on the other hand, in the fight for supreme power of communicating with god and ideological dominance by acquiring the ruling power. "Jade-as-god" view triggered the fight for resources and power among paralleled cultures, which actually was the fight for the embodiment of supernatural power. In exploring the origin of civilization, researchers used to focus on the material symbols. With the research going deeper, more and more researchers come to realize the importance of spiritual force. The jade-as-god view presents the integration of the spiritual and material forces. Spiritual force changes, so the spiritual completion never ends. The transverse force leads ultimately to the pursuit of the supreme spiritual power. Jade's communicating man and go becomes the compass that directs the spiritual force, attracting human beings with the incredibility of supernatural power and leading them into the house of civilization. The discontent for civilization development is more than the secular greed identified by Werner Sombart when he did research on the source of the capitalist spirits. This discontent that provides an upward force is already rooted in the source of civilization. Besides the secular material desires, humans also desire for spiritual resources.

For the birth of civilization, the significance of transverse force that results from the competition among regional cultures and the upward force of spiritual pursuit, "The cultural and historical meaning of the transportation of jade, different from that of the transportation of gas from the west to the east, lies in what it has brought into Chinese tradition spiritual forces, i.e. the national mainstream of core values." [15:11] Ye pointed out that, "Viewing the source of jade ware in east Asia from the perspective of mythology, the main line of Chinese mythology is jade myths and the related faiths. We can see that certain corresponding jade-as-god concept lies behind every type of jade ware. Observing the time and place of the unearthed jades, we can outline the spreading route of jade-as-god view" [15:16]. Such route predicts the direction of the driving force of civilization, which is the very theoretical focus of Ye's two main directions of explaining the civilization spreading. "According to the great tradition, from 8000 years ago to 4000 years ago, the spreading of jade culture can be simplified in two direction: from north to south and from the east to the west." [15: 22].

\section{Conclusions}

Literary narratives relevant to jade does not come out of vacuum and exist in an isolated realm. Jade tradition is the inherited practices or opinion and conventions associated with Chinese for prolong period. This also includes attitudes of the Chinese, durable interactional patterns and socio-cultural institutions. Throughout the novel, we encounter the opposition and tension between the divine and the secular, the metaphysical and the moral, the original and the derivative. Many scholars have noticed the multi-layered, double-nature, paradoxical word-play of the symbolism involved in jade. The imagery of jade is operative both on the metaphysical and the moral level, where binary oppositions are mutually transformative and non-evaluative, and the contrasting terms in binary pairs "enter into confrontational rather than complementary relationships with each other" [1: 139].

In this paper, we turn from the literary study of the jade image to jade mythology, then to the genetic or archaeological study on its mythological concepts, which is similar to the archaeology of knowledge proposed by Michel Foucault. In this way, the scope and subject of mythology extends from ancient mythological narratives in written form to the pre-writing prehistoric jade articles for worshiping purposes. To figure out the underlying motive of jade worship, we have to study the mythological concepts of jade in shaping the inward ideology and exterior behavior in the integrated view of ideological history and cultural history. The Mythological Concepts of the pre-historical tradition functions effectively to the construction of the core concepts of a given culture, just as Schilbrack holds, "The political mythological theories should be demystified, since the daily activities of political interactive texts is filled with mythological creation. There's no need to regard myths as some special ways of expression or confine beliefs to an irrational psychopathic mythology." [13:188] Schilbrack stresses that mythological concepts plays a deterministic role and prototype function in the formation and evolution of ideology. Once the prototype of jade myth is revealed, the evolvement track of its literary narratives and the operative relations between coding and re-coding will be better understood.

Jade as the gene of Chinese culture, which plays an integrated function in the material and spiritual resource possession and distribution. The critical link between mythology and cultural origin lies in the special cultural factors that mold the ideology. At the early Chinese history, jade functions as the bonding that integrate the central plains and the surrounding areas. Such bonding was both material (from the mining, exploitation, transportation, exchange to the processing and distribution of jade minerals), and spiritual (the cross-region spreading and unification of jade's mythological concept). The long-term interaction of material and spiritual demand finally brought to the eve of Chinese civilization (the era before the Bronze Age) its core values: jade as holy, jade as treasure, and jade ware as the sign to communicate man and heaven (man and god). Jade has gone through the building of Chinese civilization with various gestures, which provides us a panoramic perspective to know 
about the integrity and continuity of Chinese civilization. The continuity of Chinese civilization consists of has two related layers of meanings: first, Chinese civilization never stops from the ancient to now and still enjoys a vital energy, which enchants the west scholars; second, there is a structural continuity of belief, ritual, politics and economics within Chinese civilization system, which is proposed by $\mathrm{Tu}$ Weiming as "the continuity of being". He then introduces a peculiar omnipotent and omnipresent Chinese concept "Qi" (air) to explore the particularity of Chinese thoughts. $\mathrm{He}$ raised a question about the origin $t$ of "Qi", "in what sense do the most unintelligent substances, such as stones, and the most intelligent embodiments, such as the heaven, constitute of the same thing - Qi?" [16:6] Here, "Stones" and "heaven" listed exactly correspond to jade and "jade-as-god" ideology in the jade oriented theory. Thus, jade enjoys great potential in the illumination and interpretation of the continuity and integrity of Chinese philosophy, the inner logic of the underlying ideology and derivative tradition can be seen.

Jade narrative demonstrates the dialectical tension between the truth and the fake within myths, thus we should keep alert for the authoritative narration in history records, and realize the dialectical tension between the truth and the fake within myths, the myths' possibility and capability of narrating history. Jade mythical narratives are absolutely not the exactly account of authentic history, but it takes efforts to penetrate through the fantastic mythical narratives to perceive the authentic history or grasp the leading threats to authentic history. By elucidating the connection between mythical concepts and historical narrative, mythology successfully gets rid of the narrow discipline limitation and is regarded as the common source and the integrated origin of the modern principles, like literature, history and philosophy. The historical and rational elements in jade myths, which shed light on the dialectics of mythical narratives. The discovering of underlying relation between mythology and history, the revealing of the dialectics within mythical narration offer methodological support for the deep exploration of the jade mythology and origins of Chinese civilization.

\section{REFERENCES}

[1] Cao, Xueqin. A Dream of Red Mansions[M]. Vol. 8 of the annotated version. Beijing: Beijing Normal University Press, 1987.
[2] Weber, Max. The Methodology of the Social Sciences. Trans. Han, Shuifa et al. Beijing. Central Compilation \& Translation Press, 1999.

[3] Yuan, Ke. Foreword[M].//Anne Birrell. Chinese Mythology: An Introduction. Baltimore \& London: Johns llopkins University Press, 1993.

[4] Allan, Sarah. The Shape of the Turtle: Myth, Art, and Cosmos in Early China [M]. Albany, NY: State University of New York Press, 1991.

[5] Ye, Shuxian. Narration of Object: Quadraple-evidence Theory of the Origins of Chinese Civilization [J]. Lanzhou University Journal, 2010, 38(6): 1-8.

[6] Bernstein, Peter L. The Power of Gold: The History of an Obsession [M]. Trans. Huang, Lei. Shanghai: Shanghai University of Finance and Economics, 2008.

[7] Cassirer, Ernst. The Myth of the State [M]. Trans. Zhang, Guozhong. Zhejiang: Zhejiang People's Publishing House, 1988.

[8] Carr, Edward Hallett. What Is History [M]. Trans. Wu, Zhucun. Beijing: The Commercial Press, 1981.

[9] Yuan, Ke. Collation and Annotation to the Classic of Mountains and Seas [M]. Shanghai: Shanghai Publishing House of Classics, 1980.

[10] Na, Zhiliang. Chinese Jade Art Object (Zhongguo Gu Yu Tu Shi) [M]. Taibei: Nan Tian Publishing Press, 1990.

[11] Ye, Shuxian. The Golden Bough and the Jade LeafComparative Mythology from Chinese Perspective [M]. (Serial books of Contemporary Chinese Comparative Literature Studies) Shanghai: Fudan University, 2012.

[12] Fang, Shiming et al. Annotation to Bamboo Annals. Shanghai: Shanghai Ancients Books Publishing House, 2005. P. 213.

[13] Schilbrack, Kevin. Thinking Through Rituals [M]. London and New York: Routledge, 2002.

[14] Ye, Shuxian. Shun Issued Jades to Tribe Leaders after the Abdication from Yao: the Myth History of the Two Legendary Rulers. Nanning: Ethnic Arts Quarterly, 2012(1): 26-31.

[15] Ye, Shuxian. Cultural Semiotics -the New Horizon of the Great and Small Tradition [M]. Shaanxi: Shaanxi Normal University Press, 2013.

[16] Tu, Weiming. The Continuity of Being: Chinese Visions of Nature [J]. Research of Chinese Philosophy History, 1981, 10 (1): $1-8$ 